\title{
The influence of international law on shaping local government law in Poland
}

\section{Ben Sassi}

\begin{abstract}
The article presents selected aspects of the internationalization of Polish law in the area of local self-government after 1989. The scope of the subject is very wide, thus the author decided to choose the determinants which have directly influenced the present functioning of local self-government in the Republic of Poland. The aim of the study is to present the role of Polish international obligations in the shaping of the legislative process, and to show the significance of these commitments in the present self-government system in Poland. To realize the established aim, the author introduces the reader to the regulations of the Polish Constitution which refer to the local government and the place taken by international law in the internal legal order. In further subchapters, the author describes the impact of the legislative activity of the European Union and the Council of Europe on the shape of local government in Poland in order to summarize the conclusions of the analysis. The research was conducted by using the dogmatic method, and by analyzing the available literature in the subject matter. After 1989, due to the social and political changes, the Polish legislation (including the Constitution) opened up to the international law, which has had a significant impact on the functioning of public administration in Poland. Currently, the legal bases for the functioning of the administration in Poland are not only acts issued by the Polish Parliament and Government, but also the norms of the European Union and international law. Increasing activity in the field of EU legislation means de novo that the Polish public administration system is still evolving.
\end{abstract}

Key words: International law, local government, internationalization of law, European Union law, Council of Europe, incorporation, adaptation rights, europeanization of law

\section{Introduction}

Over the years among the most interesting objects in jurisprudence have been the functioning and organization of public authority and the influence of international regulations on national ones. This article presents just a sample to signalize the key issues; due to the formal framework of the topic, the subject could not be analyzed in detail. In the light of the structural assumptions, local government in Poland is the base for the functioning of Polish democracy. The best evidence of this is presented in the Constitution of the Republic of Poland and alludes to the principle of constituting the government. Pursuant to art. 15 sec.1, "The territorial system of the Republic of Poland shall ensure the decentralization of public power", however sec. 2 states that "The basic territorial division of the State shall be determined by statute, allowing for the social, economic and cultural ties which ensure to the territorial units the capacity to perform their public duties". According to the legislator's assumptions, all the inhabitants of local government units are de iure the community of self-government. Local government through its representatives (operating on the basis of, within and according to the law) is exercising public power under its own responsibility [Constitution 1997]. 
The reason for beginning the research was to determine the international legal conditions of the functioning of local government in Poland. In art. 9 of the Constitution of the Republic of Poland the legislator underlined that: the Republic of Poland shall respect international law binding upon it. Therefore, article 9 is the starting point in further considerations for establishing the place of international law in the legal status of local governments in Poland. This results from one of the general principles of international law - pacta sunt servanda. The rule alludes not only to international agreements but also to all international commitments by the country. Moreover, it implies the obligation to implement all international obligations and incorporate them into domestic law. The nation, using its own developed methods, has freedom of choice in the implementation process. Also, the principle of primacy of international law over domestic law is strengthened by the norms of the Vienna Convention on the Law of Treaties [1969]. However, art. 27 refers to international relations rather than domestic ones.

Art. 9 of the Constitution is a universal declaration of respect for the pacta sunt servanda rule in relation to the whole international community. The disposition of art. 9 also establishes a regulation for internal state authorities. Within the broad interpretation of art. 9 there is an obligation to not only obey the international law which binds Poland through ratified international agreements, but also respect resolutions of international organizations and bodies as well as customary law. The commitment in art. 9 concerning respecting international standards may - in some cases - take precedence over other constitutional norms. This is due to art. 9 of the Constitution, wherein Poland is obliged to implement the framework decisions of the European Union.

\section{The law of the European Union}

European legislation concerning local government is quite different. According to the Treaty on European Union - "The Union shall respect the equality of Member States before the Treaties as well as their national identities, inherent in their fundamental structures, political and constitutional, inclusive of regional and local self-government. It shall respect their essential State functions, including ensuring the territorial integrity of the State, maintaining law and order and safeguarding national security. National security remains the sole responsibility of each Member State" [TEU\&TFEU]. It can be noted that EU Treaty legislation is extremely selective in the area of local government. Poland's becoming a member state of the European Union did not entail any changes in legal acts concerning local government because the European Community does not interfere with the selfgovernment systems of its member countries. Some legislative acts, essential for governments, had to be amended to bring them in line with the EU acquis. The place of European law and its importance for local government in Poland is determined by the phenomenon of "Europeanisation of the public administration" and hence the administrative law itself. 


\section{Europeanization of the public administration}

After the transformations in 1989, as a result of integration processes and Poland's approach to Western structures (i.e. European Communities and NATO), the present shape of administrative law has been mainly outlined by international obligations, including regional solutions. It can also be noted that public administration in Poland is constantly subject to internationalization processes, mainly through integration - as a member state of the European Union - and international cooperation - by transferring certain functions of the public administration to international organizations [Niewiadomski 2010].

In Polish literature the concept of „Europeanisation” of law has been developed. It is defined as a certain system of action and theleology, specific to the cultural circle, in this case the European civilization. Such a definition of the phenomenon leads a researcher rather to issues of philosophy of the law than to dogmatic doctrines.

In Polish literature, a narrow interpretation of Europeanisation of administrative law is defined as "actual and future international commitments of Poland, which are related to belonging to the European Union". It therefore includes "not only European law as the law of the European Union, but also the effect of Poland's accession to the Council of Europe" [Jaśkowska 1999].

It is possible to distinguish the basic determinants having impact on the Europeanisation of Polish law:

1. European Union law,

2. Legislative activity of European international organizations,

3. Reception of law.

The very concept of Europeanisation is quite fuzzy. First of all, the term can be used in relation to the process of shaping the mechanisms of administrative law which are typical for EU solutions. Secondly, it can be understood as the transfer into Polish internal law of the institutions formed in member states.

What comes to mind is the legislative activity during interwar years, when Polish resolutions were a reflection of institutions formed in western countries, which were modified as a result of specific cases or practice. This kind of Europeanisation is not identified with the previously mentioned one, which only sets out certain mechanisms developed for the functioning of the European Union. It is essential to underline that both notions are fully justified in the process of examining the dogma of administrative law.

Some administrative law researchers point out that the Europeanization of Polish law might be examined in terms of gradual loss of national sovereignty. Investigators show that the state is losing its control over national public authorities - such as internal executive power. Public administration is not only focused on EU legislation itself, but also combines it with European norms. Ratified conventions, such as the European Charter of Local SelfGovernment or Convention No. 108 for the Protection of Individuals are relatively few when compared to other standards called soft law which affect EU candidate countries to a greater extent than member states. In the light of the above, there appears a very important question: will the internal law, which renounces its part of sovereignty in the name of European 
standards, not lead to blurring the lines of responsibility for the decisions made by the public administration? [Lipowicz 2008] Considering the whole process of adapting Polish law to EU standards, the author of this study claims that this is impossible because a particular citizen (who is one of the parties in administrative proceedings) in the event of a violation of his rights or inaction in proceedings or even the occurrence of a competence dispute, has, apart from national authorities, the EU authorities where he can also demand his rights. If it turns out that the Polish legislator changed the provisions in breach of the standards adopted in a democratic state of law, the citizen may assert his rights in the institutions of the European Union. This is the highest form of control over the operation of the system and the provisions of interior administrative law.

\section{Legislative practice of the Council of Europe}

After an examination of the role of international law for local governments in Poland, it should be noted that the Council of Europe occupies a special place in the doctrine. The law created within this structure provides standards for public administrative procedures and judicial control of the administrations of the Council of Europe member states. It is essential to underline that even before the European Communities, the Council of Europe had introduced a Europe-wide terminology and developed model standards for law enforcement. The European Union, and previously the ECSC and EEC, have adopted plentiful solutions from the Council of Europe.

Poland is a clear example of the above due to the fact that by joining the Council of Europe it accepted the citizens' right to file individual complaints to the European Commission of Human Rights, and consequently the mandatory jurisdiction of the Court [Izdebski 1996]. Formed international standards were the subject of Bogdan Dolnicki's research which was focused on the impact of international regulations on decentralised public administration. According to Dolnicki, the source of legal norms referred to as the local government system is the European Charter of Local Self-Government which since 1994, as a ratified international agreement, is formally binding in Poland. Since its ratification, the ECLS is in force in Poland and has a direct influence on local government legislation [Dolnicki 2005]. The preamble to the European Charter of Local Self-Government determines the role of local government in the public life of European countries. Those premises have a purely ideological character. What is necessary to underline is the relation between democracy and government included in the ECLS. Local authorities are a fundamental pillar of a democratic system, as they allow citizens to exercise their right to participate in deciding on public affairs [ChLSG 1994]. The possibility of exercising this right has a fundamental impact on the structure of a democratic system. Many Europeans claim that the protection and establishment of local government contributes to the creation of a common Europe based, inter alia, on the decentralization of public power and consequently the rule of law and democracy. Article 2 of the European Charter of Local Self-Government clearly states that the signatories are obliged to set the rules concerning self-government in their domestic legislation, beginning with the Constitution, 
and ending with legal acts. The official position of the Council of Europe (interpreted numerous times) explicitly states, that the Constitutional rules on local self-government in national law have an important meaning for the building of self-government. It can be concluded that the principles in the Constitution are a specific information for defining the principle of self-government and the position of self-government units in the state [Kieres 1998].

After 1989, local self-government reform in Poland attracted considerable interest on the part of European decision-makers. At that time, plentiful non-governmental organizations and representatives of Western countries declared their readiness to provide substantive help to the preparation of a local self-government act. Such help was often accepted by the Government Agent of Local Self-Government Reform (involved in local self-government reform in Poland). It is important to stress that without the help of the countries and institutions which had successfully introduced certain solutions in their domestic countries, the local self-government reform in Poland would have been ineffective. The help of the Council of Europe was of great importance here. The European Charter of Local Self-Government, based on democratic states' practice, was the foundation on which the Polish local selfgovernment act was created. After the presentation of the drafts of Polish self-government acts in Strasbourg, Jerzy Stępien - the senator, and Michal Kulesza - the Government Agent of Local Self-Government Reform, gained great recognition. The documents were legitimized as compliant with European standards. During their creation, the Council of Europe sent experts who played a key role in the preparation and implementation of self-government reform in Poland.

The impact of the European Charter on the public administration system and its functioning gives an essential clue for the interpretation of Polish legislation. This is due to the fact that the EC provides the basis for interpretation of law in decisions concerning individual entities and general acts, which are crucial in public administration. Poland's becoming a member of the Council of Europe in 1991 entailed huge expectations concerning administrative law doctrine; hopes were especially associated with a future reform, which would be in line with European standards. It has been often emphasized that Poland's affiliation to Europe is longlasting, and the imposed socialist regime in Poland prevented the full use of the benefits of science and the democratic practices developed in the West [Łętowski 1993]. The European Charter had a great influence on the above-mentioned provisions of the Constitution of the Republic of Poland which refer to local self-government. The principle of decentralization is inspired by the European Charter Preamble: "safeguarding and reinforcement of local selfgovernment in different European countries is an important contribution to the construction of a Europe based on the principles of democracy and the decentralisation of power" and Article 3: "local self-government denotes the right and the ability of local authorities, within the limits of the law, to regulate and manage a substantial share of public affairs under their own responsibility and in the interests of the local population" [EChLSG 1994]. The constitutional rule of presumption of consequence is also related to Art. 3 and refers to the smallest unit of local self-government, the commune. Michał Kulesza conducted extensive research on local 
self-government activity. Taking into consideration the results of Kulesza's research and the issue of legal and international conditions of local self-government in Poland, one can conclude that Polish solutions (despite their constitutional basis and the provisions contained in the Act) tend to limit the independence of the local self-government unit. Michał Kulesza points out that, in contrast to Art. 3 sec. 1, the "right" and "ability" of local communities in community management have been omitted. This is due to the fact that the general basis of law is replaced by specific solutions, also in those areas where no competent authority is provided. Such specific solutions for the activities of government are imperfect - they limit the activity of self-government to acting not only "within the limits of the law," but "within the limits of and according to the law". Kulesza rightly emphasizes that that the European Charter mentions activity "within the limits defined by law" and not "on the basis of the act" [Kulesza 2009].

\section{Summary}

As mentioned in the introduction, this paper about the legal and international conditions of local government in Poland does not exhaust the topic in its entirety. For many years this subject has been a matter of interest in doctrine. It should not be forgotten that this extremely complex issue needs to be examined through the wide context of developments in Polish legislation during the three last decades, beginning with the socialist state, through the full membership of the European Union, and ending with the international community. The conditions of international law of local self-government in Poland were formed mainly by the Council of Europe's legislative activity. The opening up of Polish legislation (including the Constitution) to European Union law and to international law in general, have had a significant impact on the foundations of the functioning of public administration in Poland. Nowadays, the legal bases for the administration in Poland are present not only in Polish legal acts, but also the norms of EU and international law. The increasing activity in the field of EU legislation means that the Polish public administration system is still evolving. 


\section{References}

BiernatS., 2002, Europejskie prawo administracyjne ieuropeizacja krajowego prawaadministracyjnego (zarys problematyki), Studia Prawno-Europejskie, 6, Wydawnictwo Uniwersytetu Łódzkiego, Łódź, pp. 71-111.

Biernat S., Niedźwiedź M., 2012, Znaczenie prawa międzynarodowego i unijnego dla prawa administracyjnego $i$ administracji publicznej w świetle Konstytucji RP, [in:] R. Hauser, Z. Niewiadomski, A. Wróbel, (eds.), System Prawa Administracyjnego, 2: Konstytucyjne podstawy funkcjonowania administracji publicznej, Instytut Nauk Prawnych PAN, C.H.Beck, Warszawa.

Chełmoński A., 1994, Polski samorząd terytorialny na tle Europejskiej Karty Samorzadu Terytorialnego, [in:] P. Buczkowski (ed.), Odrodzenie samorzadu terytorialnego. Budowa społeczeństwa obywatelskiego, II Kongres Samorządu Terytorialnego, Krajowy Instytut Badań Samorządowych, Poznań.

Dolnicki B., 2005, Ustrój samorządu terytorialnego w świetle standardów europejskich, [in:] Z. Janku, Z. Leoński, M. Szewczyk, M. Waligórski, K. Wojtczak (eds.), Europeizacja polskiego prawa administracyjnego, Kolonia Limited, Wrocław, pp. 41-52.

Izdebski H., 1996, Rada Europy. Organizacja demokratycznych państw Europy i jej znaczenie dla Polski, Wydawnictwo Naukowe Scholar, Warszawa.

Jaśkowska M., 1999, Europeizacja prawa administracyjnego, Państwo i Prawo, 54,11, p. 18.

Kieres L.,1998, Analiza zgodności polskiego prawa samorzadu terytorialnego z Europejska Karta Samorząu Terytorialnego, Samorząd Terytorialny, 9, pp. 3-80.

Kokocińska K., 2014, Prawny mechanizm prowadzenia polityki rozwoju w zdecentralizowanych strukturach władzy publicznej, Wydawnictwo Naukowe UAM, Poznań.

Kulesza M., 2009, O tym, ile jest decentralizacji w centralizacji, a także o osobliwych nawykach uczonych administratywistów, [in:] J. Supernat (ed.), Między tradycja a przyszłościa w nauce prawa administracyjnego, Księga jubileuszowa dedykowana Profesorowi Janowi Bociowi, Wydawnictwo Uniwersytetu Wrocławskiego, Wrocław, pp. 410-411.

Lipowicz I., 2008, Europeizacja administracji publicznej, Ruch Prawniczy, Ekonomiczny i Socjologiczny, 70,1, pp. 8-9.

Łętowski J., 1993, Rada Europy o postępowaniu administracyjnym, Annales Universitatis Mariae Curie-Skłodowska, Sectio G, 40, p. 93. 


\section{THE INFLUENCE OF INTERNATIONAL LAW ON SHAPING LOCAL GOVERNMENT LAW IN POLAND Ben Sassi}

Niewiadomski Z., 2010, Pojęcie administracji publicznej, [in:] R. Hauser, Z. Niewiadomski, A. Wróbel (eds.), System Prawa Administracyjnego, 1: Instytucje prawa administracyjnego, Instytut Nauk Prawnych PAN, C.H.Beck, Warszawa , p. 32.

\section{Legal acts}

Constitution of the Republic of Poland, 2 April 1997, Official Journal, 78, item 483.

Consolidated versions of the Treaty on European Union and the Treaty on the Functioning of the European Union, Official Journal of the European Union (2012, 55, C 326, 01).

European Charter of Local Self-Government, 1994, Official Journal, 124, item 607.

\section{Wpływ prawa międzynarodowego na prawo samorządu terytorialnego w Polsce}

\section{STRESZCZENIE}

W artykule zostały przedstawione wybrane przez autora aspekty związane $\mathrm{z}$ umiędzynarodowieniem prawa polskiego w aspekcie ustroju samorządu terytorialnego po 1989 r. Zakres tematyczny wybranego obszaru badawczego jest bardzo szeroki, dlatego autor wybrał tylko te determinanty, które bezpośrednio wpłynęły na obecny kształt funkcjonowania samorządu terytorialnego w Polsce. Celem opracowania jest przedstawienie czytelnikowi roli zobowiązań międzynarodowych RP w kształtowaniu procesu prawotwórczego oraz ukazanie znaczenia tych zobowiązań w obecnym kształcie ustroju samorządowego w Polsce. Realizując założony cel autor wprowadza czytelnika $\mathrm{w}$ regulacje zawarte $\mathrm{w}$ konstytucji RP dotyczące samorządu terytorialnego oraz miejsca prawa międzynarodowego w wewnętrznym porządku prawnym. W kolejnych podrozdziałach autor opisuje wpływ działalności prawotwórczej Unii Europejskiej i Rady Europy na kształt obecnego samorządu terytorialnego w Polsce, aby w podsumowaniu wyprowadzić wnioski z przeprowadzonej analizy. Autor prowadził badania metodą prawnodogmatyczną oraz przeanalizował dostępną literaturę w rzeczonym zakresie. W związku z przemianami społeczno - politycznymi po 1989 roku prawodawstwo polskie, w tym Konstytucja, otworzyły się na prawo międzynarodowe, co wywarło istotny wpływ na podstawy funkcjonowania administracji publicznej w Polsce. Podstawą prawną działania administracji w Polsce są dziś nie tylko akty wydawane przez polski parlament i rząd, ale także normy prawa unijnego i normy prawa międzynarodowego. Coraz większy udział działalności prawotwórczej Unii Europejskiej powoduje de novo kształtowanie się polskiego systemu administracji publicznej.

Słowa kluczowe: Prawo międzynarodowe, samorząd terytorialny, umiędzynarodowienie, prawo Unii Europejskiej, prawo Rady Europy, inkorporacja, dostosowanie prawa, europeizacja prawa

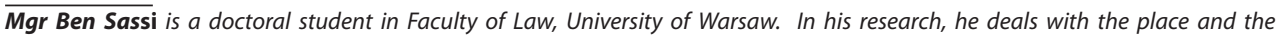
relationship of international law to domestic law. He is also organizer of international congresses supporting bilateral cooperation. Contact: ben.b.sassi@gmail.com, affiliation: University of Warsaw, Institute of International Law.

Mgr Ben Sassi jest doktorantem Wydziału Prawa i Administracji Uniwersytetu Warszawskiego na kierunku prawo. W swoich badaniach zajmuje się skutecznościa prawa międzynarodowego w wewnętrznym porządku prawnym. Zawodowo zajmuje się organizacja międzynarodowych konferencji dwustronnych wspierających wymianę handlowq. Kontakt: ben.b.sassi@gmail.com, afiliacja Uniwersytet Warszawski, Instytut Prawa Międzynarodowego.
} 